\title{
What does Al-Qanun Fi Al-Tibb (The Canon of Medicine) say on head injuries?
}

\author{
Ahmet Aciduman • Berna Arda • Fatma G. Özaktürk • \\ Ümit F. Telatar
}

Received: 26 June 2008 /Revised: 11 March 2009 /Accepted: 24 March 2009 /Published online: 13 May 2009

(C) Springer-Verlag 2009

\begin{abstract}
A historical approach could help in the detection of some viewpoints that cannot be paid attention to or signified by a purely medical one. In this text, the important points of Ibn Sina's (Avicenna) treatise on head injuries have been introduced in light of neurosurgery. The most detailed chapter regarding head injuries in Canon, under the title of "Fracture of the Skull," presents rather detailed knowledge concerning skull fractures and their surgical treatments in the eleventh century and the medical paradigm of that era. Ibn Sina provided extremely systematic knowledge on head traumas along with both his observations and experiences and citations from the writings of the ancient physicians, Galen and Paul of
\end{abstract}

This article is based on an oral presentation at the 3rd Balkan Congress on the History of Medicine, held in Thessaloniki, Greece, November 29-December 1, 2007.

\footnotetext{
A. Aciduman

School of Medicine, Deontology Department, Ankara University, Ankara, Turkey

B. Arda

School of Medicine, Deontology Department, Ankara University, Ankara, Turkey

F. G. Özaktürk

Faculty of Letters, Latin Department, Ankara University, Ankara, Turkey

Ü. F. Telatar

Faculty of Letters, Latin Department, Ankara University, 06100 Ankara, Turkey

\section{A. Aciduman $(\square)$}

Dögol Caddesi, No: 27-14,

06580 Mebusevleri,

Ankara, Turkey

e-mail: ahmetaciduman@yahoo.com
}

Aegina. Regarding the treatment of skull fractures, Ibn Sina is a real successor of Galen and Paul of Aegina.

Keywords Avicenna - Canon - Galen · Head injuries . History of medicine $\cdot$ Paul of Aegina $\cdot$ Trepanation

\section{Introduction}

In neurosurgery practice, head injuries have been frequently encountered and are one of the most important health issues, which might require surgical intervention, since humans came into being. Trepanation is the oldest well-known neurosurgical process and dates back to the Neolithic period (about $7000 \mathrm{BC}$ to 3000 BC) [25], and the oldest known written document of head injuries is the Edwin Smith Papyrus [23]. This treatise, which is from seventeenth $\mathrm{BC}$, consists of 48 cases, 27 of which concern head traumas related with deep scalp wounds exposing the skull and skull fractures. The writings of Hippocrates (460-370 BC), De Capitis Vulneribus, contained the first recorded descriptions of trepanation and the instruments and methods used [25]. Galen of Pergamon (129-200 AD) was the most important medical writer of antiquity [19]. He was the first neurosurgeon in the arena of sports as well $[6,19]$. Galen's writings served as the basis of knowledge regarding the nervous system [19]. Galen wrote a commentary on De Capitis Vulneribus, which is not extant but cited in other treatises and in Arabic sources [9]. Galen mentioned Hippocratic treatise De Capitis Vulneribus in his three works: De methodo medendi libri, In Hippocratis librum de officina medici commentarii, and In Hippocratis librum primum epidemiarum [20]. Paul of Aegina (625-690 AD) developed many instruments for cranial surgery [10], and he enlight- 
ened and influenced the Eastern World in the treatment of cranial fractures by his classic work, Epitome (The Seven Books of Paul of Aegina) [2]. Haly Abbas, the predecessor of Avicenna, wrote a chapter regarding skull fractures and their surgical treatment in his main work, Kâmil al-Sinâa al-Tibbiya (The Royal Book) [4]. In Córdoba, Albucasis (936-1013), almost contemporary of Avicenna, wrote a detailed chapter on skull fractures and described the methods of surgical treatment in his important treatise Al-Tasrif (Medical Vade mecum) with illustrations of surgical instruments used by himself $[3,5]$.

\section{Ibn Sina and Al-Qanun Fi Al-Tibb (The Canon of Medicine)}

Ibn Sina (Bukhara 980-Hamadan 1037; Fig. 1), known as Avicenna in Western World, memorized Holy Quran at the age of 10, and, at 14 years of age, with his intellect and strong memory skills, he outperformed his teachers in accumulating knowledge. Some authors emphasized that, at 16, there were physicians working alongside him. Ibn Sina, who has been respected because, when he was 18 , he cured

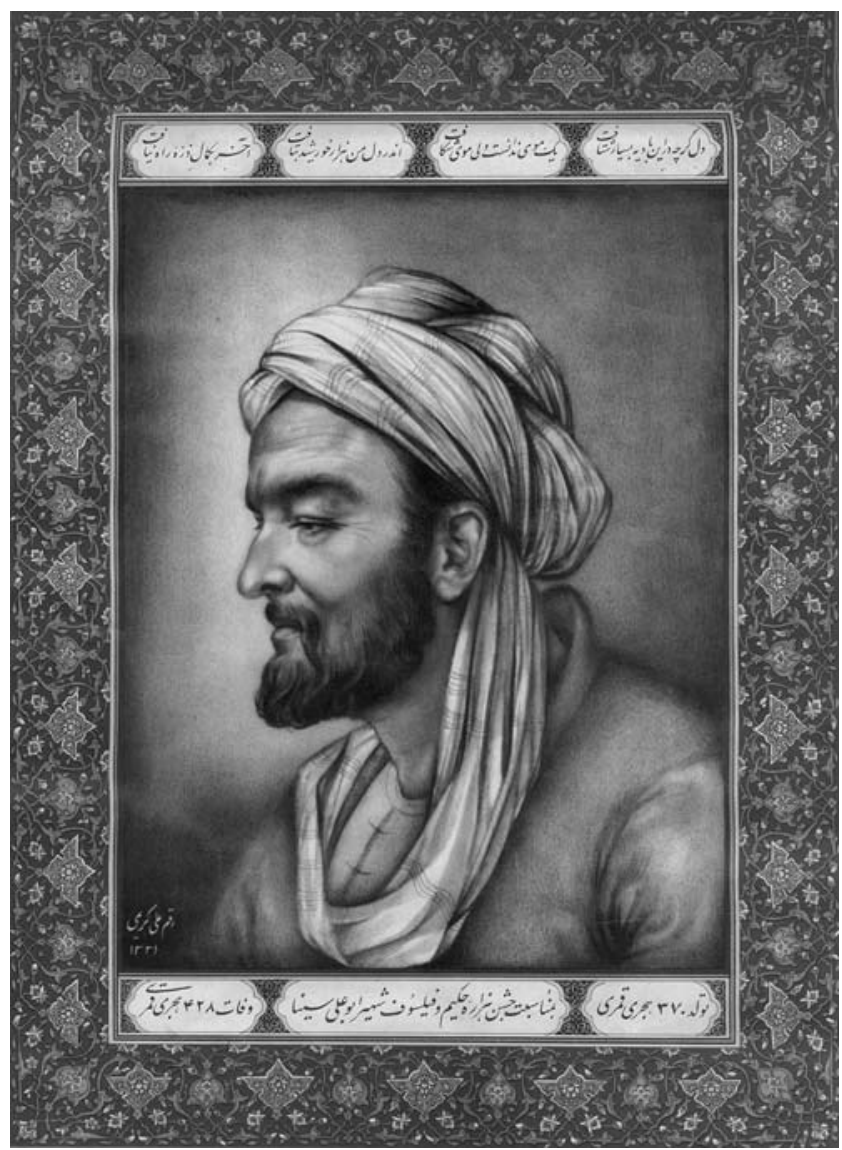

Fig. 1 A portrait of Avicenna (980-1037)
Noah II, the ruler of Samanids, is considered among the most famous and accountable scholars of his era in the fields of Quran, philosophy, mathematics, astronomy, geology, medicine, physics, chemistry, literature, et cetera. After the death of Noah II, the ruler of Samanids, he went to Khwarizm and got acquainted with Al-Bairuni. After he had left Khwarizm, he traveled to Gorgan, Qazvin, and Hamadan. During this period, he not only worked as a physician but also served as vizier for Shams Al-Dawlah in Hamadan. Sometimes, he was put in a dungeon, and sometimes he escaped from a city to another one in order to be free from malicious gossipers and generally persecutions $[18,21]$.

The Canon may be considered the best one, which attempted to coordinate systematically all medical doctrines of Hippocrates and Galen with the biological concepts of Aristotle [8]. The Canon is both epitome and the summation of Greco-Arabian medicine. What Galen did for Romans, Ibn Sina accomplished for the Moslems [21]. The Canon of Ibn Sina is divided into five large books. Each book is divided into treatises (fen), each of which in its turn is subdivided into chapters and sections systematically [8]. The Canon of Ibn Sina consists of approximately a million words and is the most influential textbook ever written; for six centuries, it dominated the medical schools of Asia and Europe. The Canon was translated into Latin by Gerard of Cremona (1114-1187) for the first time in the twelfth century. A Latin version of Canon was published in Milan in 1473 (Figs. 2 and 3). A Hebrew version appeared in Naples in 1491 (Fig. 4) and an Arabic edition of Canon in Rome in 1593 (Fig. 5) [18]. It is regarded as a law in its field, and the enquiry into Canon is regarded as sacrilege [21]. The medical approach of Ibn Sina is based on the humoral doctrine of Hippocrates, which remained as a medical paradigm dominating Eastern and Western worlds for more than 2,000 years.

\section{The chapters related to head injuries in the Canon of Medicine}

The first chapter of Canon regarding head injuries is entitled as "Head Fractures, Laceration of Scalp, et cetera $[12,15]$." In this chapter, Ibn Sina classifies the head fractures into four categories with regard to the split in the bone: (1) fracture of the bone, (2) contusion of the bone, (3) fracture extending to the slender skin of the head, (4) fracture which is not smooth or forming a curvature. According to Ibn Sina, this curvature may sometimes be in the form of a mushroom, which is called "mushroom type," and pericranium will protrude and is swollen. In this chapter, he emphasized that inflammation would spread from the fracture and wound in the head to the water 


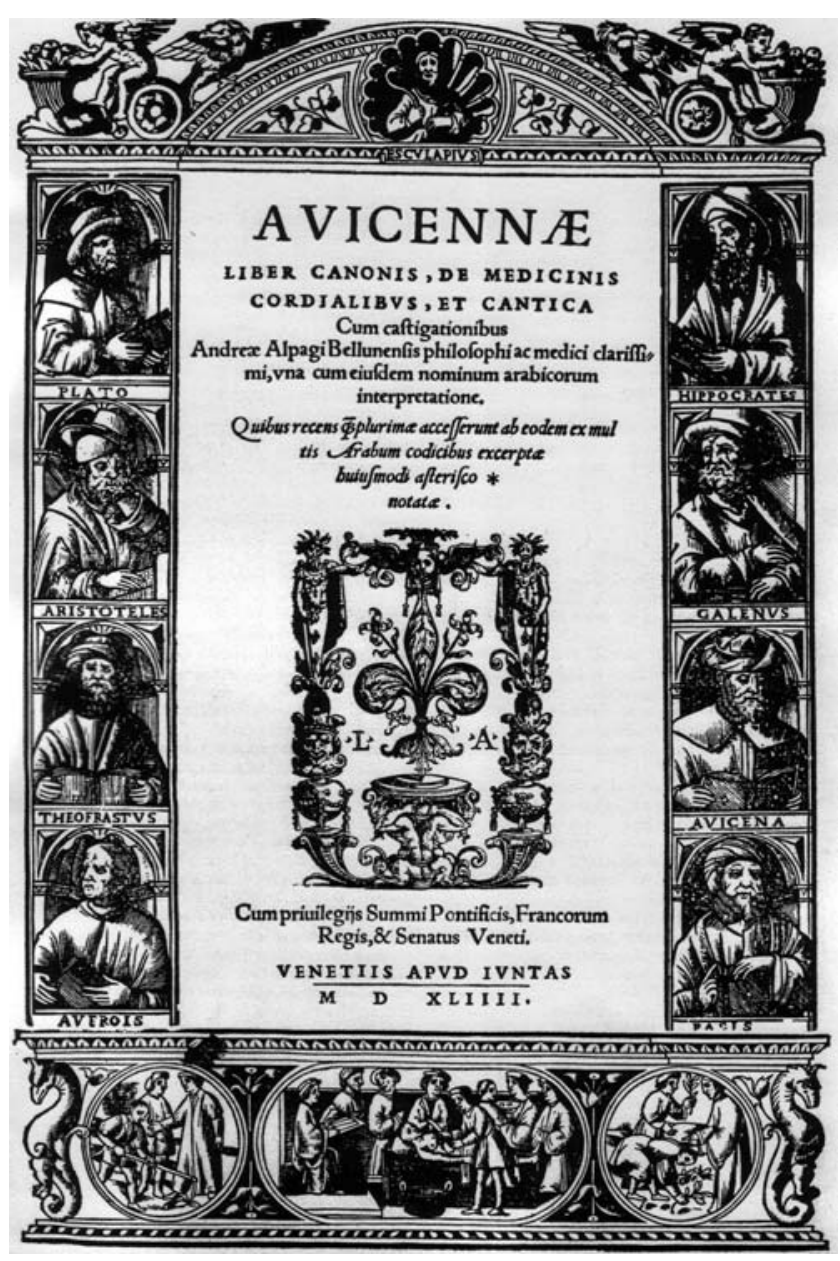

Fig. 2 Frontispiece of Latin edition of the Canon which was printed by Junta Press in 1544 in Venice [22] (from: Tamani G (1988) Il Canon Medicinae di Avicenna Nella Tradizione Ebraica: le Miniature del Manoscritto 2197 della Biblioteca Universitaria di Bologna. Editoriale Programme, Padova, p 14 [22])

membrane of brain [meningitis?]. He said that patient's condition was more serious than ever when a cut reached the brain and the ventricles:

When the cut reaches the edge of this membrane but not to the ventricles of the brain, this condition is healthier [than ever] and there is hope for recovery. When the cut reaches the brain tissue, fever and vomiting of bile occur and very few people recover from this condition. The cut in the ventricles in frontal brain is the best of all. If you immediately help and stick both sides to each other, there is hope [for recovery]. When the cut is in the ventricles of the posterior, the treatment [of this condition] is more difficult, and if the cut is in the middle ventricles of the brain, it is the worst of all and it is difficult for the patient to regain his natural self, except if the fracture - the cut-is very small and treatment is begun immediately $[12,15]$.
Ibn Sina suggests preventing the swelling with drugs as the treatment. He underlines that there are two different treatment approaches of physicians to this subject. Those in the first group prefer relieving pain and tranquilizing the patient, while the physicians in the second group prefer using drugs that would dry the cut. Ibn Sina says "after cutting off the fracture and removing the broken [pieces], smearing vinegar and honey on the head" is useful for treatment.

The second chapter devoted to head injuries, entitled as "Fracture of the Head," consists of scalp lacerations, ceasing the bleeding, wounds, and drugs to be used in treatment of swelling resulting from contusion $[13,16]$.

The most detailed chapter regarding head injuries in Canon was presented under the title of "Fracture of the Skull" (Figs. 6 and 7) [7, 14, 17]:

Sometimes skull may be fractured, but the scalp may not be lacerated, just swollen. In such a case, if you

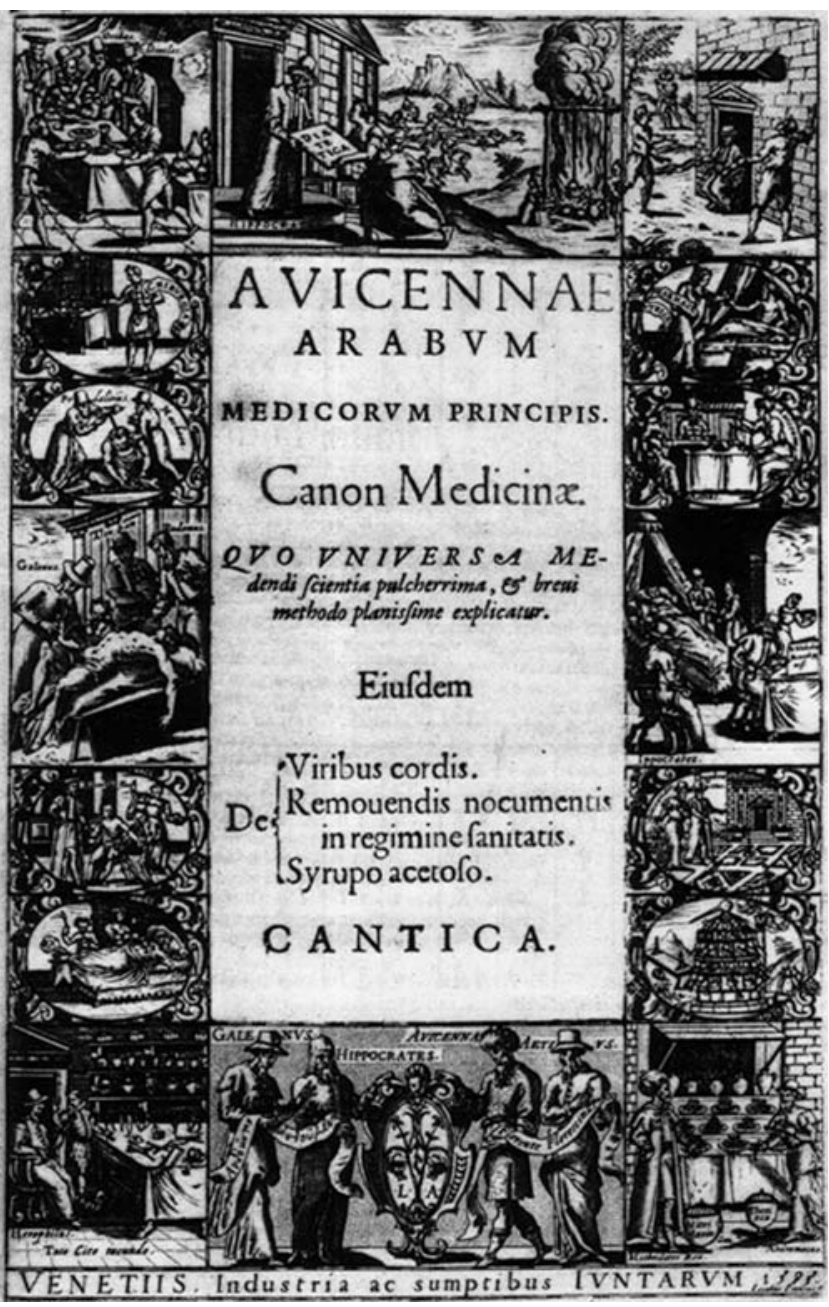

Fig. 3 Frontispiece of Latin edition of the Canon published in 1595 by Junta Press of Venice [22] (from: Tamani G (1988) Il Canon Medicinae di Avicenna Nella Tradizione Ebraica: le Miniature del Manoscritto 2197 della Biblioteca Universitaria di Bologna. Editoriale Programme, Padova, p 21 [22]) 
ipowe

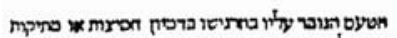

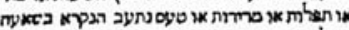

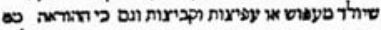
א

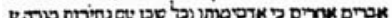
ע

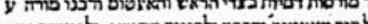

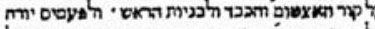

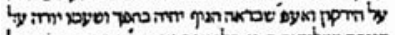

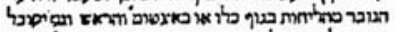

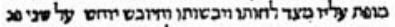

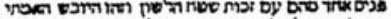

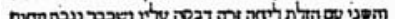

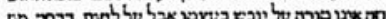

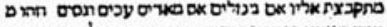

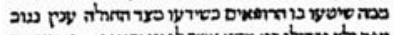

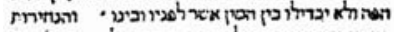

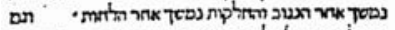

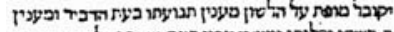

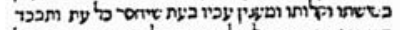

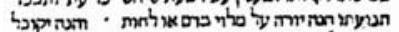

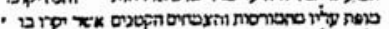

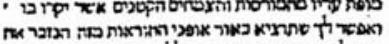
אטי בדת

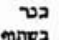

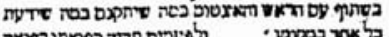

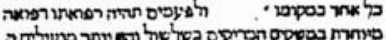

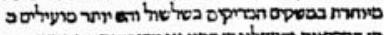

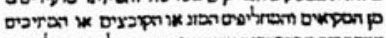
ה ל

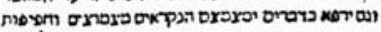

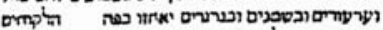
0 ט

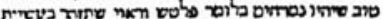

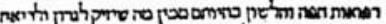

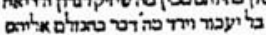

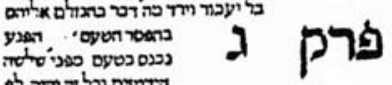

נכ20 ט

To y y מר ש

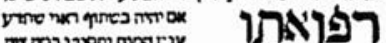

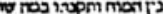

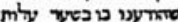

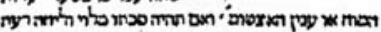

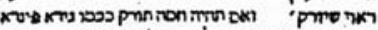

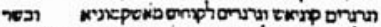
2 Pחת ש

28

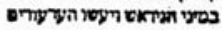

Fig. 4 A page from Hebrew edition of Canon published in Naples in 1491-1492 [22] (from: Tamani G (1988) Il Canon Medicinae di Avicenna Nella Tradizione Ebraica: le Miniature del Manoscritto 2197 della Biblioteca Universitaria di Bologna. Editoriale Programme, Padova, p 61 [22])

attempt to treat the swollen area and neglect the treatment of fracture, fractured bone may decay underneath. Before the swelling resulting from the fracture recovers and even after it recovers, dangerous implications may arise, e.g. fever, trembling, unconsciousness et cetera. Then, when the skull is fractured, you should not only treat the swelling, but also tear open the scalp so that you can observe and cure the fracture. You can often detect the fractured area by the help of the patient. The patient puts his hand on the fractured area and points out the aching area. If you observe any implications of a fracture on the skull, leave the wound and swelling as they are, and start treating the fracture. Lift the scalp so that purulent matter and fester do not accumulate in one place. This precautionary measure is necessary not only for the fractures of the head but also for all fractures of the body. Under no circumstances, should you spare an area where purulence and fester can accumulate and remain, except when you are sure that swelling does not increase but gradually reduces [7, 14, 17].

Ibn Sina, in the beginning of the text, brings into attention that the physician should examine a patient very carefully while evaluating skull fractures; if not, he would make a mistake. Therefore, he details what the physicians should do. He also emphasizes the importance of taking the story of the patient as well as the importance of examination. According to him, knowing the cause of the fracture, examining the condition of the scalp, and observing symptoms in skull fractures such as stroke, confusion, loss of voice, and implications are really important factors in evaluating the patient's condition with a skull fracture [7, 14, 17].

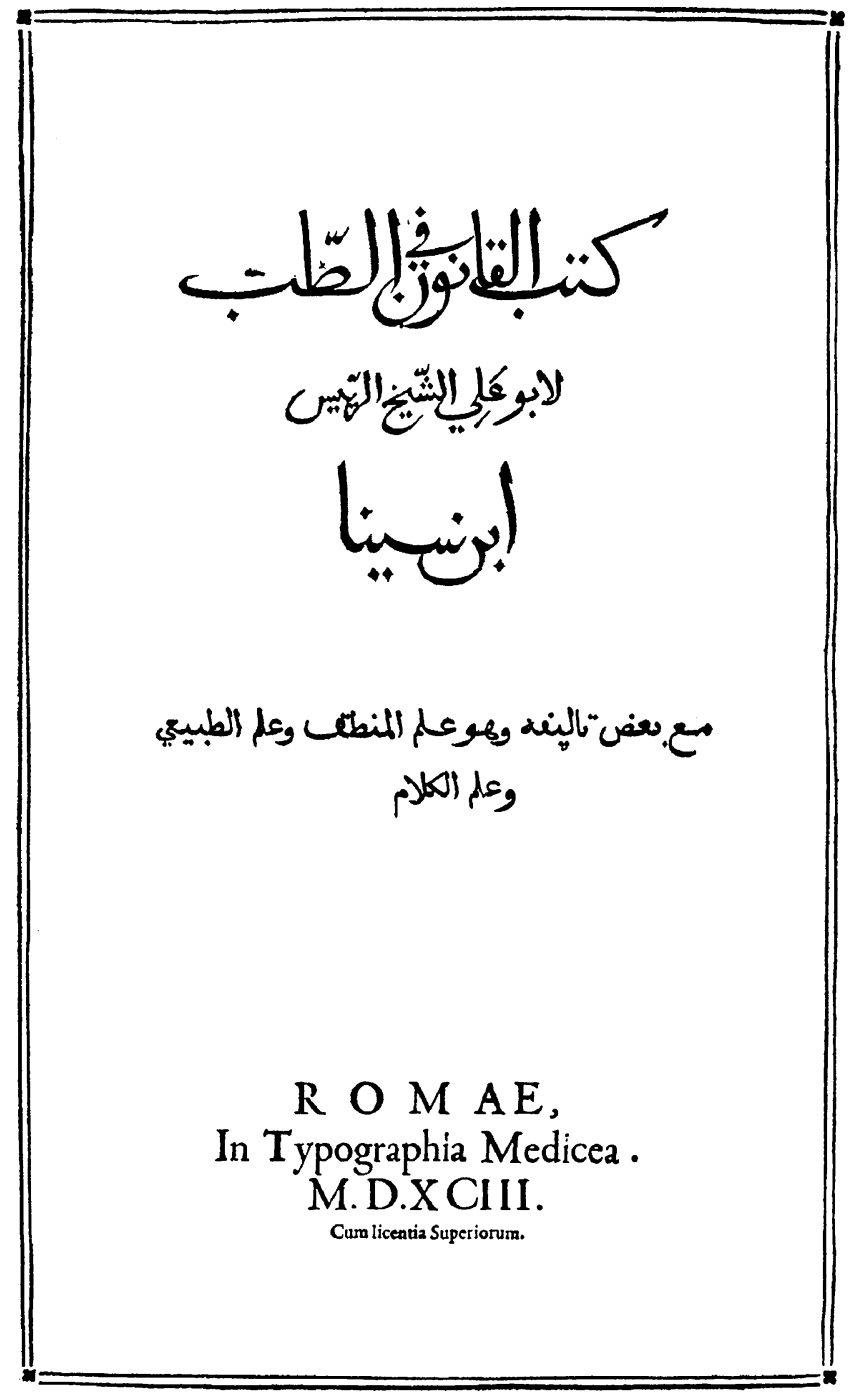

Fig. 5 Frontispiece of Arabic edition of Canon printed in Roma in 1593 [22] (from: Tamani G (1988) Il Canon Medicinae di Avicenna Nella Tradizione Ebraica: le Miniature del Manoscritto 2197 della Biblioteca Universitaria di Bologna. Editoriale Programme, Padova, $p$ 48 [22]) 
Tractatus. IIt.

466

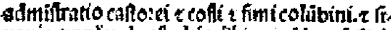

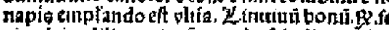

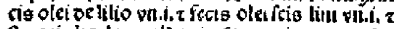
flozacis ligde $z$ galbam $\tau$ rerzprini z oppo. oius

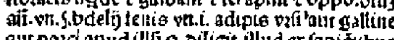

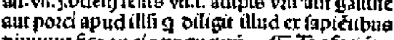

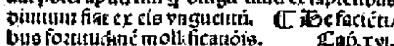

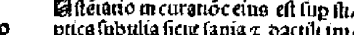
mattrit t bis fitiz:alus iug fuprice fop 3. Er gino niffer

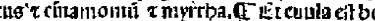

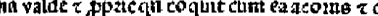
His vitis cum adipe antiqua $z$ cozriccs gratula rumpaline,z onmisiague dicta tume inuldurat do alro bootb. I Beadmiltratone zaueca

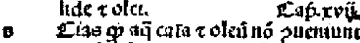
apud retautrattioneti qní,plbbent re

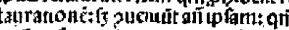
ambo pieparït reftaurgationem $x$ puentüt pof

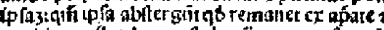

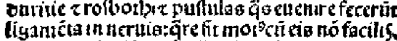

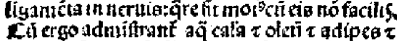

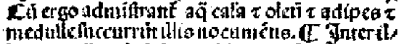

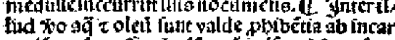

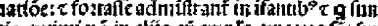

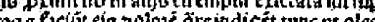

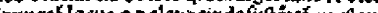

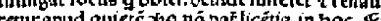

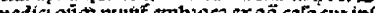

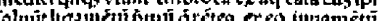
(1)

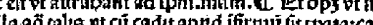

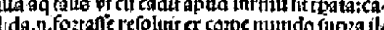

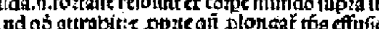

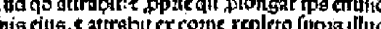
nis cills.s attribitex rotpe repleto fupza illid

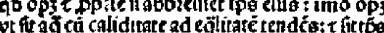

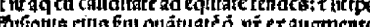

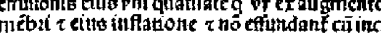
pit oetumefere. Et no qo tấ oixint" oc iud çija embsoccin caplo oiflocatións illud qó op efifte oolor eft pt tron anpropinduer membzo

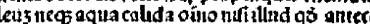

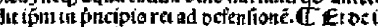
pering poretion cunt oacuti z alleliou crolindo. IT ionc reftaurati z potione eius. Sa.rviü. pooster pefít cibuo riths ex eigōges

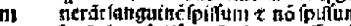

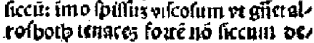

bilélçaé:t flla funt heatpedea ₹ frumétũ coct cí mults aqua quoufog fit fietut puls 2 ventires

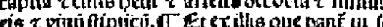

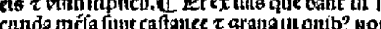
canda méla funt caltanec $\tau$ granalli quib? Ho

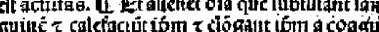

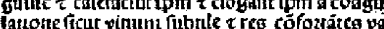

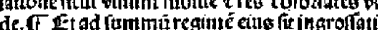

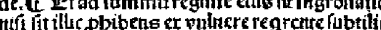

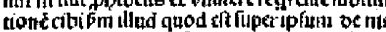
gnitudiuc cius attiof fute puttate $\tau$ apud timo

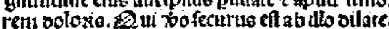

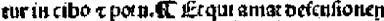
enciptar cum reginthe fubtilläte ot fecturectur.

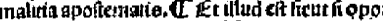
eat incru be fiobotomet z foluactar venter : inde ooft bies poucos adminiltrat ofind sui

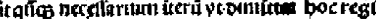
men quando fuphtuit rof botb in nugnitudite

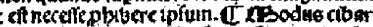

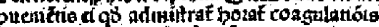
tia défnula $x$ foriga ri3i z lopum vace pinghio z lac $x$ fiat ex cis clbartiogfe tro meato cocto vi pulo cuñ bonitak fue cóluet dinio.medicina aurent elus quam fumit ad re tauratiosicm mumia es que ef nutrablia.

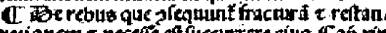

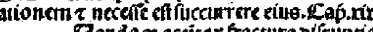

$q$ carnia que nó cóglutinót. $g$ f f nó ici darar putrefit 2 putrefscit ills quod

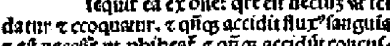

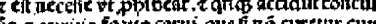
alp a che

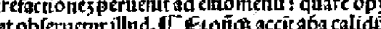
action accirapa calida Qino atimozace ops ver regatur regie fluo: q q

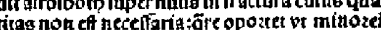
norrim bhing

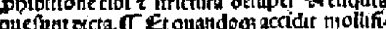
cario inneurarume ex extenfore, Er qualsdoc acadit yt currar virue ad ninedulla que genera in offe: quare necefic eft me cruabatur os 2 of

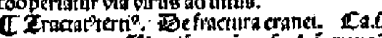
eltotics accit vo find at crane thon fildatur curtsitno abef. Cum ergo ocaipatio fit in cu rattohe apoltelizatio z nópertue sutur ad plagam forrafle accudic

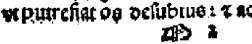

Fig. 6 The beginning page of skull fracture in Liber Canonis printed in Venice in 1507, fo.r. 466 [7] (from: Avicenna (1964) Liber Canonis. Georg Olms Verlagsbuchhandlung, Hildesheim, $\mathrm{f}^{\circ}$. r. 466 [7])

Ibn Sina describes a special type of skull fracture, "capillary," quoting from Hippocrates and Paul of Aegina, without any reference to their names:

Sometimes there may be a fracture in the skull but we cannot consider it a fracture. A split of hair-thin may be seen in that part of the skull, but it may not have reached the lower layer of the bone and have remained superficial. This may not even be visible in some cases. This kind of injury is not essentially a fracture, and it is the easiest one of the fractures to treat and you should be less worried than in any other condition. In this case, you will scrape the bone. If this split of hair-thin, which is on the upper layer of the bone, is not well visible, pour the black colored fluid onto it to make it appear. Then, scrape and clear it up until no trace is left $[7,14,17]$.

Ibn Sina emphasizes the importance of cleaning the fracture area for not only skull fractures but also all fractures of the body. He recommends removing the dirt from the bone when skull is cracked and the split reaches down to the lowest layer of the cranium. Ibn Sina says that, after examining the cover of the brain [dura mater], if it is in its normal state, there will be less damage and, if it has lost its normal state, there will be great danger. In conditions involving cracks in the skull, Ibn Sina claims that it usually recovers by binding and bandaging; thus, he recommends bringing together two sides of the wound gap and suturing when required, dressing the wound with medications, and making the patient rest and keep still $[7,14,17]$.

Ibn Sina provides the treatment principles of comminuted skull fractures and describes the healing process of the bones of the skull bones, which, he believes, affects the treatment process.

Do not have the idea of removing the fractured bone in each kind of fissure or fracture of the skull, which

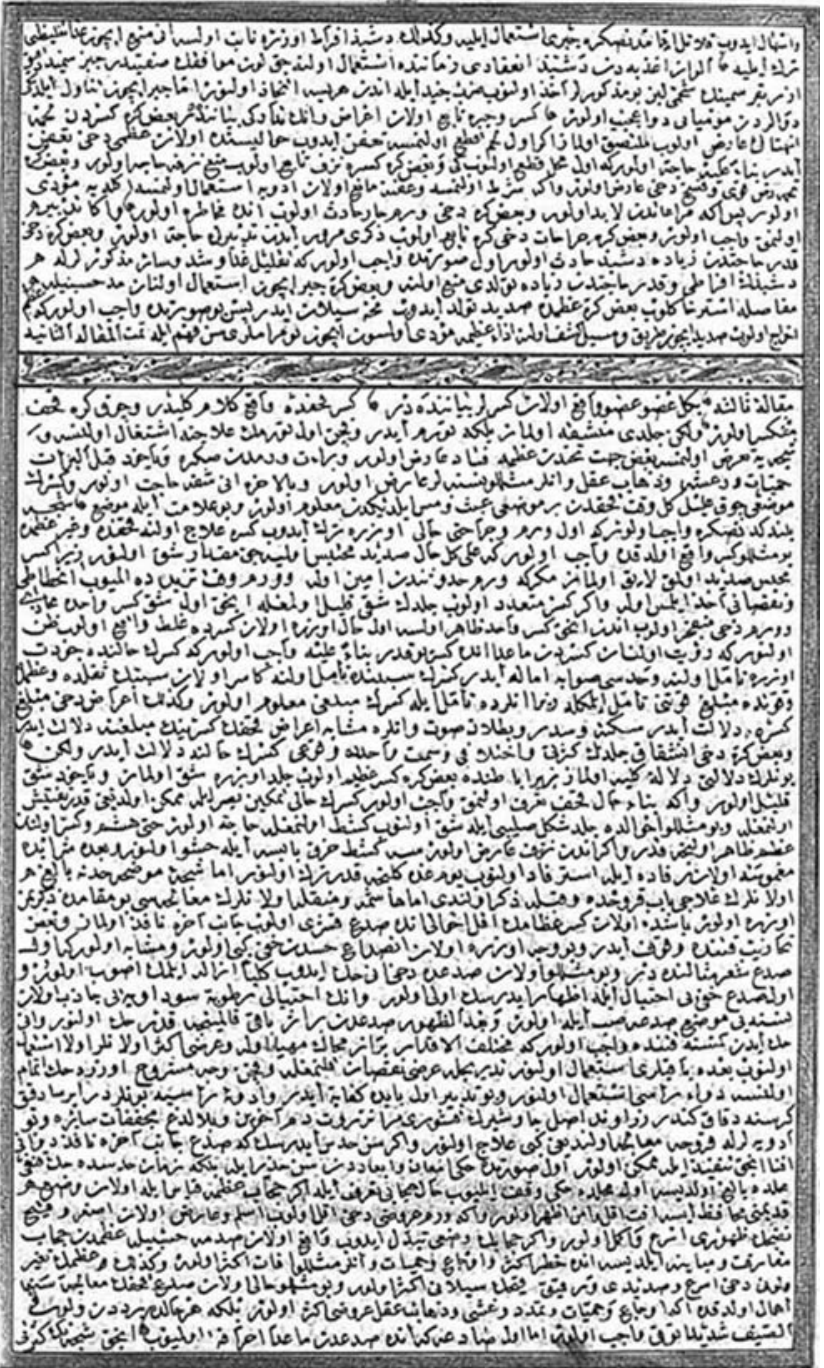

Fig. 7 The beginning page of the Canon for skull fracture in Hamidiye 1015 manuscript, f 527 b [in Ottoman Turkish] [17] 
is impossible anywhere, anyway, but, do not forget our advice on general fracture and its treatment and execute it. Rarely is it seen that the bone is taken out from someone's fractured head, and the scalp and flesh have covered the fracture area and the patient has survived. When a part of the skull is fractured in bits and pieces, you should know that the bones of the skull are different from the other bones [of the body] and so, the treatment [principles] of the fractures of the skull differs from that of other fractures [in body] as well. If the skull is fractured, nature cannot place a strong and rigid patch on the fracture as it does on other bones. The patch of the skull is weak and a less enduring one. Both for this reason and to prevent pus and dirt of the wound from penetrating the fracture and when you have diagnosed that the fracture is a complete one, remove the fractured bone and if the fracture is not complete and holds on a side, cut the fracture and do not occupy yourself with its fusion $[7,14,17]$.

Regarding the timing of the treatment of a skull fracture, Ibn Sina suggests not to delay the treatment more than 7 days in summer and more than 10 days in winter [7, 14, 17]. Ibn Sina explains why skull fractures should be treated by cutting and removing the fractured bone of the skull in his own words:

Why do I insist on the treatment of a skull fracture and say that seeing the bone bare and cutting and removing the fractured bone are necessary? Because:

1. If the fractured bone is not of the skull, but of another organ other than the skull, bandage it to stop harmful matters from penetrating the fracture- which I explained. This folded bandaging is not possible on the head.

2. In treatment of bone fractures of the organs other than the skull, a certain amount of bone needs to be cut and elevated to have pus and watery filth drain out of the fracture easily and if there is pus in the bone, we still need to cut the bone so that this pus and filth-as I pointed out before- do not combine with bone marrow and make trouble.

If fractures in other bones are like this, why should not we take the same measures in fractures of the skull? In fractures of the bones other than those of the skull, tying, bandaging, wrapping a splint et cetera protect them from adaptation of bad matters, but this is impossible in the skull, so we should be more protective in skull fractures. As required and as much as possible, cutting, elevating, and cutting the scalp and flesh over the fractured bone should be performed on the exposed fracture and the fractured skull should not be fused unless you are sure of bad signs will not develop [7, 14, 17].
For surgical intervention, he first recommends estimating and determining the most appropriate area where pus and filth will collect and which will be cut easily, away from the nerves. According to Ibn Sina, if the physician has determined an indication for elevation of the bone, he should do so immediately before inflammation develops. Bone pressure on the dura mater or bone piercing of the dura mater, of modern times, are the indications for "the cut and removal of the bone" in skull fractures. In his own words:

If you realize that cutting and extracting a part of the bone is required, immediately start working and do not wait for pus and filth to appear. If you think of waiting for sufficient pus accumulation and then cutting the bone, this is possible in some cases and does no harm. But, if the thin sheet- the main sheet that covers the brain-has been under pressure because of the skull fracture or if something has penetrated it, immediately and without hesitation, you should begin to take it out. Even when the smallest piece of bone penetrates this main sheet, not even piercing it, swelling and spasm appear very fast and brain stroke of patient is possible, and when stroke emerges, you should take the piercing bone out, under this condition: very swiftly and without hesitation. Normal sense of the brain may recover, but if this piece has pierced the main sheet, the deed is more difficult and needs to be done more swiftly. When the skull has been fractured and the sheet covering the brain has been visible, and this sheet is swollen-it is called 'mushroom'-treatment should be started immediately without any breaks. If you have to delay the treatment, it should not be delayed more than two or three days and usually treatment is required in the second, you must have learned the treatment of such cases earlier [7, 14, 17].

On technical details of the operation, Ibn Sina suggests that the operation should be performed with very thin saws and declares that touching the cover of the brain with a drill and saws will be dangerous. While he is describing the operation, he refers to "the ancient" and says that he agrees with them. After he defines the shaving of the hair of the patient, the most convenient position of the patient for the surgeon, and the scalp incisions, he tells us how to cope with bleeding which may be confronted. The statement of "put cotton or wool into patient's ear so that he will not be tired of the noise of the saw and not be injured" shows us his ethical perceptions. If the bone, which will be cut, is soft or weak, he suggests cutting it with thin saws without inflicting any damage to the membrane and the intact tissues of the brain. If the bone is tough and 
strong, he describes the removal procedure as drilling holes side by side using a special drill with a projection on the thinner tip, which will prevent damage to the membrane of the brain. After quotations from Galen regarding safe surgical techniques and amount of bone which will be cut, Ibn Sina explains the method of dressing the wound after the operation. He uses rose oil and vinegar. He suggests not bandaging tightly and recommends the use of drugs that will bond the flesh (granulation tissue) $[7,14,17]$.

After the operation, using a quotation from Paul of Aegina, Ibn Sina mentions a complication, in which the membrane may swell and the swollen membrane may rise above the skull as far as the scalp [cerebral edema?], and tries to determine the causes of this complication. In order to reduce swelling, Ibn Sina suggests drawing blood, using anti-inflammatory drugs, and, if they prove useless, inducing diarrhea in the patient as treatment methods [7, 14, 17]. In suggesting diarrhea, Ibn Sina refers to Hippocrates as: "Hippocrates approves making the patient have diarrhea $[14,17]$." Ibn Sina says that darkening of the membrane of the brain [Cl.Perfringens?], if not caused by drugs, is an indicator of a bad condition and, if other bad symptoms appear, he says the treatment should be abandoned, quoting Paul of Aegina [7, 14, 17]. Ibn Sina finishes this chapter with quotations from Paul of Aegina and Galen, explaining good prognosis of patients who underwent surgery because of skull fractures:

Paul of Aegina continues his orations and commands: "I saw someone whose head was fractured. They had removed all the broken bones from his head; one year later, the man completely recovered." This situation, which Paul of Aegina has commanded, probably occurred when an arrow had hit his head and fractured the uppermost part of the head and was not fixed in the bone and came obliquely to the bone so that it did no harm to the membrane and membrane was saved from being ruined.

Galen commands: "Someone was brought to me. The uppermost bone had been fractured, and at the same time, the temporal bone was fractured, as well. I never touched the temporal bone; I cut only a part of the damaged bone section. That was sufficient, and the man recovered" $[7,14,17]$.

\section{Discussion}

Ibn Sina described skull fractures as linear (including capillary type), comminuted, and depressed fractures [7, $14,17]$, resembling contemporary skull fracture classification, but they were different from Hippocrates' and Paul of Aegina's classifications [2, 11]. In De Capitis
Vulneribus, Hippocrates classified skull fractures as fissured, contused, depressed, dinted, and countercoup fractures [11]. In Epitome, Paul of Aegina classified the skull fractures into six types: a fissure, an incision, an expression, a depression, an arched fracture, and, in infants, dent $[2,10]$. He also mentioned the capillary fracture, which would be included in this classification [2]. Hippocrates believed that fissured, dinted, and contused types of skull fractures required trepanation since these types of fractures would be followed by serious consequences, such as inflammation, extravasation of blood, and the effusion of matter [24]. While Avicenna was repeating preventive trepanation idea in linear fractures in agreement with his predecessors, Hippocrates and Galen, he interrogated this idea by writing "If you do not worry about leaking of the pus and watery blood inside, cutting the bone will not be required." This approach may be considered a conservative treatment choice in skull fractures in Canon. Interestingly, Hippocrates was against trepanation in cases of depressed skull fractures and offered to wait until granulation tissue grew and lifted the depressed bone [20, 24]. Contrary to this approach, Galen and Paul offered trepanation and wound exploration and removal of bony fragments as the treatment for such injuries, once the danger of injury to the meninges from free bone fragments was detected $[2,20]$. In accordance with Galen and Paul, Ibn Sina suggested elevating the bone immediately in depressed cranial fractures. In order to elevate the bone, the main indications determined by Ibn Sina were (1) if the dura mater was under pressure because of the skull fracture or something penetrated the dura mater, (2) if the skull was fractured and the dura mater appeared and was swollen, (3) when the skull bone was fractured completely or the fracture was not complete and held onto a side since the patch of the skull was weak [7, $14,17]$. In the first and second indications, Ibn Sina pointed out emergency operation indications in skull fractures in fact [1]. Ibn Sina considered the bone pressure on the brain and penetration of the bone into the brain due to a skull fracture and symptoms such as spasm and brain stroke, which were associated with these conditions, as surgical indications [7, $14,17]$. This approach may be considered an early attempt to evaluate the neurologic status in skull fractures [1], which appeared as "the concept of function" in France with Jean Lois Petit (1674-1750) and Henri Francois Le Dran (16851770) [19]. Both the explanation of a safeguarding surgical technique and the amount of bone to be cut out were also found as quotations from Galen in the Canon of Medicine.

Avicenna's operation technique quoted from Ancients was from the Epitome of Paul of Aegina, who was another milestone in the history of neurosurgery, indeed [2]. Avicenna quoted Paul in operation technique, dressing the wound after the operation, describing a complication following the operation, and following up the patient $[2,7,14,17]$. In 
order to reveal a capillary fracture, using black liquid medicine and scraping the bone were the methods barrowed from Hippocrates [11], without ever citing his name by Paul of Aegina and Ibn Sina in Epitome and Canon [2, 7, 14, 17].

Ibn Sina transferred what Galen and Paul said on skull fractures to other generations and thus prevented this information from being lost, thereby serving to these Great Masters, whom he deeply respected. The language used by Ibn Sina when he cited his predecessors is really interesting. While transferring the words of physicians, who preceded him, he speaks as: "Galen commands," "Paul commands," and, when he agrees with their ideas, he behaves modestly by saying "I say." This is really important in showing the modesty and respect of one who came to be renowned as the Prince of Physicians to his old masters [1].

\section{Conclusion}

Chapters in Canon on head injuries, especially on "Fracture of the Skull," present rather detailed knowledge concerning skull fractures and their surgical treatments in the eleventh century and the medical paradigm of that era. Ibn Sina provided highly systematic knowledge on head traumas along with both his observations and experiences and citations from the writings of the Ancient physicians, Galen and Paul of Aegina. Regarding the treatment of skull fractures, Ibn Sina is a real successor of Galen and Paul of Aegina.

Although many books written on head traumas present the comments based on Hippocrates' De Capitis Vulneribus and some similarities are seen in some sections of skull fractures of Canon, Ibn Sina cited Hippocrates once and only with respect to medical treatment, not surgical, which is really striking.

Medicine did not exist until Hippocrates invented it.

When he died, Galen revived it.

It was blind; Huneyn bin Ishak gave it eyes. Al-Razi bestowed on it coherence.

And Ibn Sina made it a whole and hale (al-Juzcani, eleventh century).

Acknowledgement We thank Sehriyar Sems D.M.D. for his valuable contribution of translating the Persian text.

\section{References}

1. Aciduman A, Arda B (2007) On skull fractures in Ibn Sina (Avicenna)'s treatise Al-Qanun Fi Al-Tibb (The Canon of Medicine). In Papavramidou N, Kazazi D, Christopoulou-Aletra H editors. Abstract Book of 3rd Balkan Congress on the History of Medicine, 200729 Nov-1 Dec, Thessalanoniki, Greece, 2007, p 9
2. Aegina P (1846) The seven books of Paulus Aegina (translation and commentary: Adams F), Vol 2. Sydenham Society, London, pp 429-442

3. Albucasis (1973) On surgery and instruments (translation and commentary, Spink MS, Lewis GL). The Wellcome Institute of The History of Medicine, London, pp 698-711

4. Ali ibn Abbâs al-Majûsî (1294 AH/1877) Kâmil al-Sinâa alTibbîya [The Royal Book], vol 2. Al-Matba'at al-Kubrâ al-'Âmire [Great Imperial Printing-office] (Bûlâq), Cairo, pp 501-504 (Arabic)

5. Al-Rodhan NRF, Fox LF (1986) Al-Zahrawi and Arabian neurosurgery, 936-1013 AD. Surg Neurol 26:92-95

6. Apuzzo MLJ, Wang MY, Hansen B, Skiba J, Berry C, Levy ML (2002) Honored guest presentation: the legacy of Galen of Pergamon. The neurosurgeon in the arena of sport. Clin Neurosurg 49:333-370

7. Avicenna (1964) Liber Canonis. Georg Olms Verlagsbuchhandlung, Hildesheim, $\mathrm{f}^{\mathrm{o}} \cdot \mathrm{r}^{\mathrm{o}} 466-\mathrm{f}^{\mathrm{o}} \cdot \mathrm{v}^{\mathrm{o}} 468$

8. Castiglioni A (1958) A history of medicine, 2nd edn. Alfred A. Knopf, New York, pp 270-273

9. Galva CR (2004) Hanson, Hippocrates: on head wounds. http:// www.omega.cohums.ohio-state.edu/mailing_lists/BMCR_L/2000/ 0193.php. Accessed 29 February 2004

10. Goodrich JT (1994) Landmarks in the history of neurosurgery. In: Rengachary SS, Wilkins RH (eds) Principles of neurosurgery. Wolfe, London, pp 1.1-1.25

11. Hippocrates (1952) Hippocrating writings (trans, Adams F). In: Hutchins RM (ed) Great books of the western world, 10. Hippocrates, Galen. Encyclopedia Britannica, Chicago, pp 63-70

12. Ibn Sina (1997) Kanun der Tibb [The Canon of Medicine] (trans: Sharafkandi A), book three, part one. Soroush, Tehran, pp 102103 [in Persian]

13. Ibn Sina (1997) Kanun der Tibb [The Canon of Medicine] (trans: Sharafkandi A), book four. Soroush, Tehran, pp 436-437 [in Persian]

14. Ibn Sina (1997) Kanun der Tibb [The Canon of Medicine] (trans: Sharafkandi A), book four. Soroush, Tehran, pp 573-581 [in Persian]

15. Ibn Sina. Tahbizu'l-Mathun Tercemetu'l-Kanun [The Canon of Medicine] (trans, Mustafa Ibn Ahmed Ibn Hasan et-Tokati). Suleymaniye Library of Handwritten Works, Manuscript no: Hamidiye 1015, Istanbul, $f^{\circ}$ 244a [in Ottoman Turkish]

16. Ibn Sina. Tahbizu'l-Mathun Tercemetu'l-Kanun [The Canon of Medicine] (trans, Mustafa Ibn Ahmed Ibn Hasan et-Tokati). Suleymaniye Library of Handwritten Works, Manuscript no: Hamidiye 1015, Istanbul, fo 510a [in Ottoman Turkish]

17. Ibn Sina. Tahbizu'l-Mathun Tercemetu'l-Kanun [The Canon of Medicine] (trans, Mustafa Ibn Ahmed Ibn Hasan et-Tokati). Suleymaniye Library of Handwritten Works, Manuscript no: Hamidiye 1015, Istanbul, fo 527b-529a [in Ottoman Turkish]

18. Kahya E (1995) Introduction, the life and studies of medicine and other sciences of Ibn-i Sina. In: Ibn-i Sina. El-Kanun Fi't-T1bb [The Canon of Medicine] (Translator: Kahya E), First book. Atatürk Kültür, Dil ve Tarih Yüksek Kurumu, Ankara, pp XIXXLIII [In Turkish]

19. Liu CY, Apuzzo MLJ (2003) The genesis of neurosurgery and the evolution of the neurosurgical operative environment: part 1 prehistory to 2003. Neurosurgery 52:3-19

20. Missios S (2007) Hippocrates, Galen, and the uses of trepanation in the ancient classical world. Neurosurg Focus 23(1):E11

21. Robinson V (1944) The story of medicine, reprinted. The New Home Library, New York, pp 160-164

22. Tamani G (1988) Il Canon Medicinae di Avicenna Nella Tradizione Ebraica: le Miniature del Manoscritto 2197 della Biblioteca Universitaria di Bologna. Editoriale Programma, Padova, pp 14, 21, 48, 61 (Italian)

23. Wilkins RH (1964) Neurosurgical classic XVII. J Neurosurg $21: 240-244$ 
24. Wilkins RH (1965) Neurosurgical classic XXXVI. J Neurosurg 23:117-125

25. Wilkins RH (1996) History of neurosurgery. In: Wilkins RH, Rengachary SS (eds) Neurosurgery, vol 1, 2nd edn. Mc GrawHill, New York, pp 25-36

\section{Comments}

Raimund Firsching, Magdeburg, Germany

This historical vignette of Avicenna and his contribution to neurotrauma presented by Aciduman and collaborators is of great help for several reasons. Arabic literature has not received the attention it deserves until now, mostly because of the obstacle of translation. The canon by Avicenna gives evidence of a high standard of medicine in the eleventh century after Christ, which at the epitome of Greco-Arabian science reflects the best knowledge available on the subject of head injury at the time. It contains detailed recommendations on what to do with scalp wounds, fractures, lesions of the dura, and intracranial hemorrhage. Some issues are as controversial today as in the days of Avicenna. There is still professional disagreement which fractures require an operation with what kind of urgency. The authors are to be congratulated on this detailed report.

William T. Couldwell, Salt Lake City, USA

In this paper, Dr. Aciduman and colleagues have described the management of head injuries presented by Ibn Sina in the eleventh century Canon of Medicine, likely the most influential medical text ever written when it is considered how long it was authoritative. The fact that head injuries and their management were so well described indicates the prevalence of this type of injury and morbidity and mortality associated with such injuries in this era. The descriptions are remarkably detailed and systematic. I find it interesting that the integrity of the dura, depressed fragments pressing on the dura, and pressure under the dura were recognized as important factors in determining the outcome of the injury and, in some cases, indications for surgical intervention. The authors are to be congratulated for bringing this remarkable work to our attention. 